\title{
Chemotactic Receptor of Cord Blood Granulocytes to the Synthesized Chemotactic Peptide $\boldsymbol{N}$-Formyl-Methionyl-Leucyl-Phenylalanine
}

\author{
HIROYUKI NUNOI, ${ }^{(20)}$ FUMIO ENDO, SHOJI CHIKAZAWA, TOSHIO NAMIKAWA, AND \\ ICHIRO MATSUDA
}

Department of Pediatrics, Kumamoto University Medical School, 860 Kumamoto, Japan

\begin{abstract}
Summary
Chemotactic mobility of cord blood granulocytes (CBG) was studied under varying concentrations of synthesized chemotactic peptide, $\boldsymbol{N}$-formyl-methionyl-leucyl-phenylalanine(f • Met-LeuPhe). The maximal chemotactic mobility was found at a concentration of $2 \times 10^{-7} \mathrm{M}$ in $\mathrm{CBG}$ and $1 \times 10^{-7} \mathrm{M}$ in adult blood granulocytes $(\mathrm{ABG})(n=8)$. The maximal distance of granulocyte mobility of CBG was significantly shorter than that of ABG $(P<$ 0.01 ). The number of chemotactic receptors and the affinity constant were assayed by the competitive inhibition method, using f • Met-Leu- $\left[{ }^{3} \mathrm{H}\right] \mathrm{Phe}$, and the data were subjected to Scatchard analysis. The number of chemotactic receptors of ABG was 2.5fold of CBG, as shown by $21,800 \pm 7800$ per cell in $\mathrm{ABG}(n=3)$ and 9000 in CBG $(n=1)$. This figure was confirmed by the one point assay method by increasing the sample numbers of cord blood. It was found that bound chemotactic peptide $\left(\times 10^{-14}\right.$ moles $/ 10^{7}$ cells) was $7.9 \pm 0.7$ in $\mathrm{ABG}(n=4)$ and $3.4 \pm 0.7$ in CBG $(n=5)$. Affinity constants were similar in CBG and ABG.
\end{abstract}

\section{Speculation}

Reduced chemotactic mobility in cord blood granulocytes is attributable to the decreased number of chemotactic receptors and the disturbed association between cell surface receptors and intracellular metabolism.

Cellular chemotactic dysfunction of neonatal granulocytes has been reported by numerous investigators $(5,6,7,9,13,18)$. Underlying mechanisms, however, are still not clearly understood. Since Schiffman et al. (15) found that a formyl peptide, such as $N$-formyl-methionyl-leucyl-phenylalanine (f-Met-Leu-Phe), had a highly potent chemotactic ability, this peptide has been used for the studies of chemotactic mobility. From the point of view of reproducibility and standardization of chemotactic mobility of the granulocytes, the use of synthesized peptide, as an attractant, is desirable. The purpose of this paper is to report the results of an investigation on the response of cord blood granulocytes (CBG) to synthesized chemotactic peptide, compared to adult blood granulocytes $(\mathrm{ABG})$. The results obtained may explain the incidence of increased susceptibility to severe infection in the neonatal period.

\section{MATERIALS AND METHODS}

Chemotactic peptide. The synthesized peptide $N$-formyl-methionyl-leucyl-phenylalanine (f-Met-Leu-Phe) was purchased from the Protein Research Foundation, Osaka, Japan. Labeled peptided, $\mathrm{f} \cdot \mathrm{Met}-\mathrm{Leu}-\left[{ }^{3} \mathrm{H}\right] \mathrm{Phe}$ (specific activity $46.4 \mathrm{Ci} / \mathrm{mmole}$ ), was purchased from the New England Nuclear Corporation. This labeled peptide was purified on a Dowex 50W-X2 with $0.01 \mathrm{~N}$ $\mathrm{HCl}$, as described earlier (19). The purified peptide was stored at $4^{\circ} \mathrm{C}$ and used, after being neutralized with $0.1 \mathrm{~N} \mathrm{NaOH}$.
Cell preparation. Cell preparation was performed by a modification of the method of Böyum (2). Cells were isolated from the heparinized $(10 \mathrm{unit} / \mathrm{ml})$ peripheral blood $(100-200 \mathrm{ml})$ of healthy adult volunteers, or from the heparinized cord blood (10-50 ml) of full term neonates (body weight 2800-3400 g). Blood was mixed with one-fourth to one-half volume of $5 \%$ high molecular weight dextran (MW, 200,000-100,000 Wako Pure Chemical Industries, Ltd.) in normal saline. The erythrocytes were allowed to sediment for $60 \mathrm{~min}$ at room temperature. The leucocyte-rich fraction was then centrifuged on Ficoll-Conray (Specific gravity, 1.078) density gradients at $500 \times g$ for $30 \mathrm{~min}$. The mononuclear cell layer from the top of the gradient and the Ficoll-Conray solution were gently aspirated and discarded. The granulocyte-rich pellets were exposed to $0.87 \% \mathrm{NH}_{4} \mathrm{Cl}$ solution for $30 \mathrm{~min}$ at $4^{\circ} \mathrm{C}$ in order to lyse contaminating red cells (reticulocytes and some times erythroblasts especially in case of cord blood). It was found that the incubation period for 15 or 30 min resulted in the similar binding activity of $\mathrm{ABG}$ and $\mathrm{CBG}$ receptor for chemotactic peptide. After washing two times with the incubation buffer $\left(1.7 \mathrm{mM} \mathrm{KH_{2 }} \mathrm{PO}_{4}, 8 \mathrm{mM}\right.$ $\mathrm{Na}_{2} \mathrm{HPO}_{4}, 117 \mathrm{mM} \mathrm{NaCl}, 0.15 \mathrm{mM} \mathrm{CaCl}, 0.5 \mathrm{mM} \mathrm{MgCl}, \mathrm{pH}$ 7.2) cell pellets were again suspended in the same buffer at the density of $10^{8}$ cells $/ \mathrm{ml}$. For the assay of chemotactic mobility, purified granulocytes were washed with and resuspended in Hank's solution.

Chemotaxis assay. Chemotactic peptide was dissolved in $0.6 \mathrm{ml}$ of dimethylsulfoxide and diluted to $2 \times 10^{-4} \mathrm{M}$ with phosphate buffered saline. Further dilutions to obtain different concentrations of the peptide were performed with Hank's solution.

The chemotactic assay was performed by a minor modification of the agarose method (12). The agarose plate was prepared by placing $5 \mathrm{ml}$ of $1.2 \%$ agarose (Sigma type II) in Hank's solution containing $10 \%$ inactivated polled human serum into a $60 \times 15$ $\mathrm{mm}$ Falcon plastic petri dish. After the agarose gelled, sets of two wells with $3-\mathrm{mm}$ diameters were punched $3 \mathrm{~mm}$ apart in a straight row in the agarose plate, with a stainless steel punch. These wells were filled with $10 \mu \mathrm{l}$ of cell suspension $\left(10^{8} / \mathrm{ml}\right.$ in Hank's solution) and chemoattractant, respectively). After $3 \mathrm{~h}$ of incubation in a $5 \% \mathrm{CO}_{2}$ incubator at $37^{\circ} \mathrm{C}, 100 \%$ methanol was poured into the dishes and decanted after $30 \mathrm{~min}$. This was followed by fixation in $35 \%$ formaldehyde solution for $10 \mathrm{~min}$. The agarose gel was then removed, and the migration of cells toward the chemoattractant was compared to the migration towards the opposite side. The first parameter was defined as chemotactic mobility and the last parameter as random migration. The distances of migration were measured with a micro projector (zooming $3 \mathrm{~mm}$ distance up to a $10 \mathrm{~cm}$ distance).

$f \cdot$ Met-Leu- $\left[{ }^{3} H\right]$ Phe binding assay. The binding assay of $f \cdot$ MetLeu- $\left[{ }^{3} \mathrm{H}\right] \mathrm{Phe}$ to granulocytes was performed, after the method of Williams et al. (19) with modification. Granulocytes suspension $\left(10^{8} / \mathrm{ml}\right)$ in the incubation buffer and $\mathrm{f} \cdot$ Met-Leu- $\left[{ }^{3} \mathrm{H}\right] \mathrm{Phe}$ solution $(10 \mathrm{nM})$ diluted with unlabeled $\mathrm{f} \cdot$ Met-Leu-Phe at a given concentration were preincubated at $37^{\circ} \mathrm{C}$ for $5 \mathrm{~min}$, separately. After 100 $\mu \mathrm{l}$ of cell suspension and $20 \mu \mathrm{l}$ of labeled peptide solution were 
mixed, incubation was performed at $37^{\circ} \mathrm{C}$ for a predetermined time with gentle shaking. Incubations were terminated by rapidly diluting the reaction mixture with $3 \mathrm{ml}$ of ice cold incubation buffer, followed by rapid filtration of the mixture through $1.0 \mu$ pore size millipore filter (EAWP 25, Millipore Corporation). They were washed with $6 \mathrm{ml}$ of ice cold incubation buffer, then dried and placed into $15 \mathrm{ml}$ of ACS II scintilant (Amersham Corporation). Radioactivity was measured in a liquid scintillation spectrophotometer at an efficiency of approximately $32 \%$ (Pakard, TRICARB, B 2450). Nonspecific binding was defined as the amount of binding not inhibited by a large excess $(0.1 \mathrm{mM} ; 10 \mu \mathrm{l})$ of unlabeled $\mathrm{f}$. Met-Leu-Phe, and was usually equal to about 20-30\% of total count bound. Specific binding was defined as the total amount of labeled peptide bound minus the nonspecific binding.

\section{RESULTS}

Chemotaxis and random migration of granulocytes of cord blood and adult blood. Chemotaxis and random migration of granulocytes measured at a varying concentrations of $\mathrm{f} \cdot$ Met-Leu-Phe (from $2 \times 10^{-10} \mathrm{M}$ to $2 \times 10^{-5} \mathrm{M}$ ) are shown in Figure 1. The maximal chemotaxis of $\mathrm{CBG}$ was obtained at $2 \times 10^{-7} \mathrm{M}$ of peptide, and that of $A B G$ at $l \times 10^{-7} \mathrm{M}$. The maximal distance of chemotactic mobility of $\mathrm{ABG}$ was significantly longer than that of CGB $(P<0.005)$. Random migrations were similar between the granulocytes of adult blood and cord blood.

Biologic activity of $\left.f \cdot M e t-L e u-\Gamma^{3} H\right] P h e$. Chemotactic biologic activity of $\mathrm{f} \cdot \mathrm{Met}-\mathrm{Leu}-\left[{ }^{3} \mathrm{H}\right] \mathrm{Phe}$ was indistinguishable from that of unlabeled $\mathrm{f} \cdot$ Met-Leu-Phe (results are not shown).

Kinetics of $f \cdot$ Met-Leu- $\left[{ }^{3} \mathrm{H}\right]$ Phe binding. The specific binding of f. Met-Leu- $\left[{ }^{3} \mathrm{H}\right] \mathrm{Phe}(10 \mathrm{nM})$ to ABG is demonstrated in Figure 2. The specific bindings reached equilibrium within $12-15 \mathrm{~min}$. The incubation time was fixed at $12 \mathrm{~min}$ in the present study. The reversibility of $\mathrm{f}$. Met-Leu-Phe binding was tested by adding a large excess $(0.1 \mathrm{mM} ; 10 \mu \mathrm{l})$ of unlabeled $\mathrm{f}$.Met-Leu-Phe to an equilibrated mixture of labeled peptide and granulocytes. As demonstrated in Figure 2, f.Met-Leu- $\left[{ }^{3} \mathrm{H}\right]$ Phe binding to granulocytes was displaced with unlabeled peptide at the rate of $35 \%$ of the saturation level, after $15 \mathrm{~min}$ of incubation.

Competitive inhibition and Scatchard plot of $\cdot \cdot \mathrm{Met}-\mathrm{Leu}-\left[{ }^{3} \mathrm{H}\right] \mathrm{Phe}$ binding in granulocytes. The competitive displacement of the binding of $\left.\mathrm{f} \cdot \mathrm{Met}-\mathrm{Leu}-{ }^{3} \mathrm{H}\right] \mathrm{Phe}$ to granulocytes with the increasing concentrations of unlabeled $\mathrm{f} \cdot$ Met-Leu-Phe is shown in Figure 3a. The results obtained were subjected to Scatchard analysis $(1,14)$ (Fig. 3b). The calculated parameters are shown in Table 1, in which the equations are calculated by the method with the least squares. The slopes of the lines obtained by calculation of the

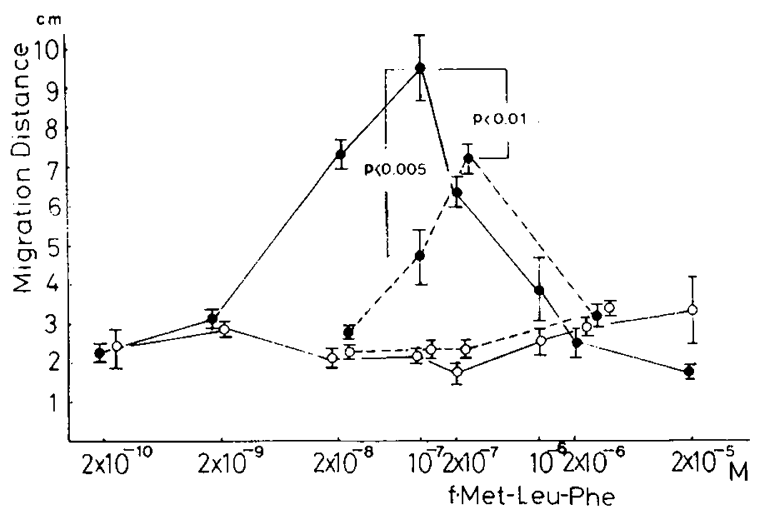

Fig. 1. Comparison of chemotaxis and random migration of adult blood granulocytes (ABG) and cord blood granulocytes (CBG). (1) Chemotaxis (O) and random migration $(O)$ of adult blood granulocytes $(-)$ and cord blood granulocytes (---) were investigated by a modified agarose method. Granulocytes were incubated in $5 \% \mathrm{CO}_{2}$ incubated $37^{\circ} \mathrm{C}$ for $3 \mathrm{~h}$. The distances of migration were measured with a microprojector (the 3-mm well diameters were zoomed up to $10 \mathrm{~cm}$ ). Data show mean \pm standard error $(n=8)$.

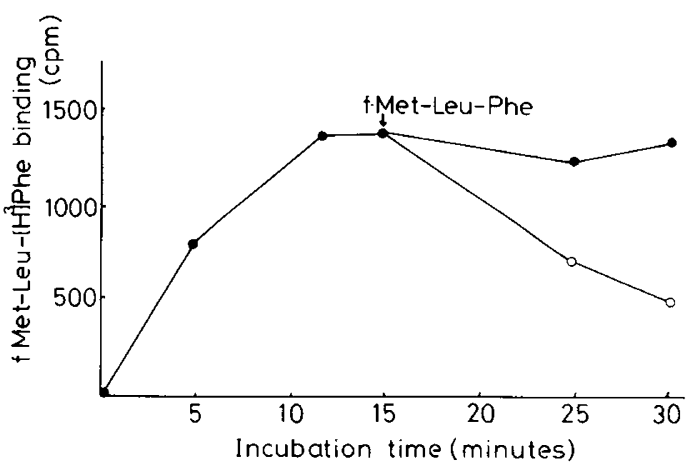

Fig. 2. Time course of $f \cdot M e t-L e u-\left[{ }^{3} H\right]$ Phe binding to granulocytes. $f \cdot$ Met-Leu- $\left[{ }^{3} \mathrm{H}\right] \mathrm{Phe}(10 \mathrm{nM})$ was incubated with granulocytes for the indicated intervals at $37^{\circ} \mathrm{C}$, and the specific binding was assayed $(\bullet)$. To some incubation mixtures $(O)$, a large excess of unlabeled $f \cdot$ Met-Leu-Phe $(0.1$ $\mathrm{mM}, 10 \mu \mathrm{l})$ was added after $15 \mathrm{~min}$ of incubation. The specific binding was assayed at subsequent intervals.
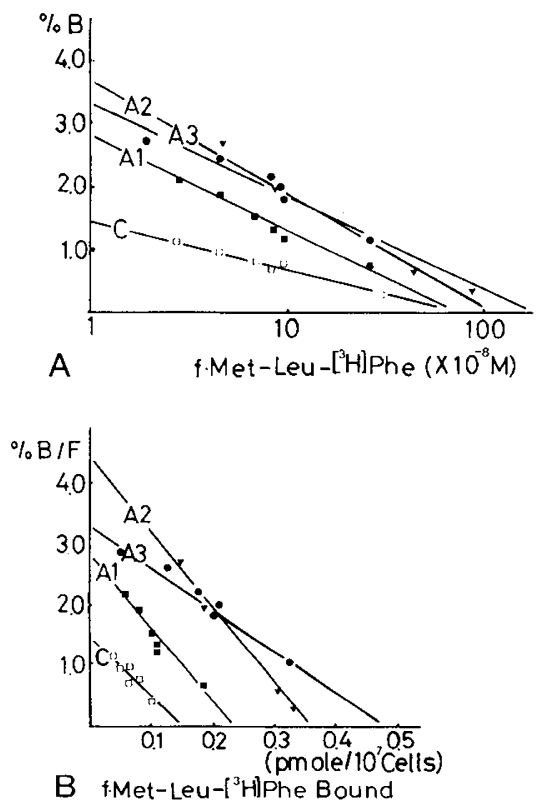

Fig. $3 \mathrm{~A}$ and B. $3 A$, Competitive inhibition. $3 B$, Scatchard plot. $10 \mathrm{nM}$ of $\mathrm{f} \cdot$ Met-Leu- $\left[{ }^{3} \mathrm{H}\right]$ Phe was competitively inhibited by unlabeled peptide at the given concentrations. Each straight line was calculated by the method of least squares. Scatchard plots were pointed after calculation from a competitive curve. $(\boldsymbol{\nabla}),(\boldsymbol{\nabla}),(\boldsymbol{)})$, and $(O)$, demonstrate the points of the competitive inhibition plot and the Scatchard plot of adult blood-1, -2, -3, and cord blood-1.

regression coefficient were significant $(P<0.05-0.005)$. For this analysis $50-100 \mathrm{ml}$ of total blood was necessary, and because of the limited supply of cord blood available, only one sample was studied for this purpose. The affinity constant was similar in $A B G$ and $\mathrm{CBG}$. The number of chemotactic receptors of $\mathrm{CBG}$ corresponded to approximately $40 \%$ that of $\mathrm{ABG}$.

One point binding assay for $f \cdot \mathrm{Met}-\mathrm{Leu}-\left[{ }^{3} \mathrm{H}\right]$ Phe to granulocytes. One point binding assay was performed on $\mathrm{CBG}$ and $\mathrm{ABG}$ at the concentration of $27 \mathrm{nM} \mathrm{f} \cdot \mathrm{Met}-\mathrm{Leu}-\left[{ }^{3} \mathrm{H}\right] \mathrm{Phe}$. As shown in Table 2, the mean of bound peptide of $\mathrm{CBG}$ corresponded to approximately $40 \%$ that of $\mathrm{ABG}$.

\section{DISCUSSION}

Chemotactic dysfunction of CBG has been clearly defined by many investigators $(5,6,7,9,13,18)$. In $C B G$, response to varying concentrations of chemotactic factor, however, has not been examined, nor compared to ABG. It was shown in the present study 
Table 1. Scatchard analysis of chemoattractant by granulocytes

\begin{tabular}{|c|c|c|c|c|c|c|c|}
\hline Material & Equation ${ }^{\prime}$ & $r^{2}$ & $P$ & Receptor $^{3}$ & $\mathrm{Kd}^{4}$ & $\mathrm{Ka}^{4}$ & $N^{5}$ \\
\hline \multicolumn{8}{|l|}{ Adult } \\
\hline 1 & $\mathrm{Y}=-1.1 \mathrm{X}+2.8$ & 0.916 & $<0.05$ & 14,000 & 9.1 & 1.1 & 6 \\
\hline 2 & $Y=-1.2 X+4.4$ & 0.997 & $<0.005$ & 22,000 & 8.3 & 1.2 & 4 \\
\hline Mean & & & & 21,000 & 10.5 & 1.0 & \\
\hline$\pm \mathrm{SD}$ & & & & 7,800 & 3.2 & 0.3 & \\
\hline Cord 1 & $Y=-1.0 X+1.5$ & 0.959 & $<0.005$ & 9,000 & 10.0 & 1.0 & 6 \\
\hline
\end{tabular}

${ }^{1}$ Equations are calculated by the method of least squares [Y, \% bound/free and X, bound peptide $\left(\times 10^{-13}\right.$ moles $/ 10^{7}$ cells or $\left.\left.120 \mu \mathrm{l}\right)\right]$.

${ }^{2} r$, coefficient of correlation.

${ }^{3}$ Receptor, the number of receptor sites per granulocyte.

${ }^{4} \mathrm{Ka}$ and $\mathrm{Kd}$, apparent affinity constant $\left(\times 10^{7} \mathrm{M}^{-1}\right)$ and apparent dissociation constant $\left(\times 10^{-8} \mathrm{M}\right)$.

${ }^{5} \mathrm{~N}$, number of points that are used on a Scatchard plot.

Table 2. One point assay of binding of granulocytes for $f \cdot$ MetLeu- $\left[{ }^{3} H\right] P h e^{1}$

\begin{tabular}{lll}
\hline \multicolumn{1}{c}{ Material } & \% Bound/free & $\begin{array}{c}\text { Bound peptides } \\
\left(\times 10^{-14} \text { moles } / 10^{7} \text { cells }\right)\end{array}$ \\
\hline $\begin{array}{lll}\text { Adult } \\
1\end{array}$ & 2.45 & 7.7 \\
2 & 2.18 & 7.0 \\
3 & 2.80 & 9.0 \\
4 & 2.52 & 7.9 \\
Mean \pm S.D. & $2.44 \pm 0.22$ & $7.9 \pm 0.7$ \\
Cord & & \\
1 & 1.04 & 3.3 \\
2 & 0.64 & 2.0 \\
3 & 1.22 & 3.9 \\
4 & 1.25 & 4.0 \\
5 & 1.10 & 3.6 \\
Mean \pm S.D. & $1.04 \pm 0.21$ & $3.4 \pm 0.7$ \\
\hline
\end{tabular}

${ }^{1}$ One point binding assay was performed at the concentration of $27 \mathrm{nM}$ of $\mathrm{f} \cdot$ Met-Leu- $\left[{ }^{3} \mathrm{H}\right]$ Phe.

that the concentration of synthetic chemotactic peptide to produce the maximal mobility of CBG was two times higher than that of ABG. Furthermore, the maximal distance of chemotactic mobility was significantly less than that of $\mathrm{ABG}$.

These data suggest that several dysfunctions are susceptible, namely: a decreased number of chemotactic receptors, decreased affinity for chemoattractant and impaired intracellular metabolic response to chemotactic stimulation.

In order to clarify these possibilities, receptor analysis was performed with $\mathrm{f} \cdot$ Met-Leu- $\left[{ }^{3} \mathrm{H}\right] \mathrm{Ph}$. The time course pattern of binding with labeled peptide and displacement with unlabeled peptide showed that the binding is specific, as was proven in early report (19). The results of the competitive inhibition method, obtained under concentrations from $2.0 \times 10^{-8} \mathrm{M}$ to $100 \times 10^{-8}$ $\mathrm{M}$, gave a single class of the binding of peptide-receptor complex on Scatchard analysis. The calculated number of chemotactic receptors ranged from $15,000-30,000$ sites per cell in $A B G$ and 9000 in CBG. Synderman et al. (17) reported that saturated concentrations of bound $\mathrm{f} \cdot \mathrm{Met}-\mathrm{Leu}-\left[{ }^{3} \mathrm{H}\right] \mathrm{Phe}$ were approximately $45 \mathrm{fmole} / 10^{6}$ human granulocytes. This value corresponds to 27,000 binding sites per cell. On the other hand, Williams et al. (19) showed that $\mathrm{f} \cdot \mathrm{Met}-\mathrm{Leu}-\left[{ }^{3} \mathrm{H}\right] \mathrm{Phe}$ was saturable, approaching a value of $20-80 \mathrm{fmole} / \mathrm{mg}$ protein, corresponding to about 2000 binding sites per cell. Other reports, using a neutrophil-derived crystal-induced chemotactic factor (16) instead of chemotactic peptide, proposed $6.4 \times 10^{5}$ binding sites per cell. It is interesting to note that in the present study, CBG possesses approximately $40 \%$ fewer chemotactic receptors than $A B G$. One point assay method, by increasing the number of cord blood samples, also showed that the specific bound peptide to $C B G$ was approximately $40 \%$ of ABG. It was shown in another report (4) that the number of $F c$ receptors and complement binding receptors was reduced in the granulocyte obtained from blood of premature infants. Al- though the number of samples was limited in the present study, the affinity constant was similar in CBG and ABG. The value of the affinity constant in our study was 4-10-fold higher than those reported in the literatures $(15,17,19)$. The discrepancy between our results and other investigators' may be attributed to the differences in the experimental methods used.

With regard to the dissociation constant $(\mathrm{Kd})$ and chemotactic mobility, it was found that the $\mathrm{Kd}$ value of $\mathrm{ABG}$ was about 10 times higher than the concentration needed to give half maximal chemotactic response $\left(1.0 \times 10^{-8} \mathrm{M}\right)$. On the contrary, the $\mathrm{Kd}$ value of $\mathrm{CBG}$ was almost similar to the concentrations producing half-maximal response $\left(1.0 \times 10^{-7} \mathrm{M}\right)$. These results suggest that, in spite of the similar affinity constants of $\mathrm{ABG}$, in order to effect the maximal chemotaxis, the number of receptors as well as their share is to be greater in $\mathrm{CBG}$ than in $\mathrm{ABG}$.

Therefore, in addition to the decreased number of receptors of CBG, the disturbed association between receptors and intracellular metabolism might be related to chemotactic disfunction of CBG. Although the molecular mechanisms of chemotactic response is not clearly understood, rigid and decreased deformability of neonatal granulocytes membrane, as was found earlier $(3,8$, $10,11)$, seems to be one of the possible causes of the disturbed coupling of cell surface receptors and intracellular metabolism.

Other possible mechanisms should be studied in the future.

\section{REFERENCES AND NOTES}

1. Baxter, J. D. and Funder, J. W.: Hormone receptors. N. Engl. J. Med., 301: 1149 (1979).

2. Böyum, A.: Separation of leucocytes from blood and bone marrow. Scand. J. Clin. Invest. Suppl., 97: 1 (1968).

3. Harris, R. E., Boxer, L. A., and Beahner, R. L.: Consequences of vitamin E deficiency on the phagocytic and oxidative functions of the rat polymorphonuclear leulocyte. Blood, 55: 338 (1980).

4. Ishikawa, M.: Fc and complement receptors of neutrophils in premature infants and adult. Jikeikai Med. J., 95: 697 (1980).

5. Klein, R. B., Fisher, T. J., and Gard, S. E.: Decreased mononuclear and polymorphonuclear chemotaxis in human newborns, ingants, and young children. Pediatrics., 60: 467 (1977).

6. Laurnti, F., Ferro, R., Marzetti, G., Rossini, M., and Bucci, G.: Neutrophil chemotaxis in preterm infants with infections. J. Pediatr., 96: 468 (1980).

7. Laurenti, F., La Geca, G., Ferro, R., and Bucci, G.: Transfusion of polymorphonuclear neutrophils in premature infant with klebsiella sepsis. Lancet, 2 (8080): 111 (1978).

8. Lichtmann, M. A.: Cellular deformability during maturation of the myeloblast; Possible role in marrow egress. N. Engl. J. Med., 283: 943 (1971).

9. Miller, M. E.: Chemotactic function in the human neonate. Pediatr. Res., 5: 487 (1971).

10. Miller, M. E. and Myers, A. K.: In vitro measurements of leukocyte deformability: An aid in the study of chemotaxis and random motility of human PMNs. Fed. Proc., 33: 798 (1974).

11. Miller, M. E.: Developmental maturation of human neutrophil motility and its relationship to membrane deformability. Bellanti, J. A. and Dayton, D., (Eds) The phagocytic cell in host resistance. National Institute of child health. Raven Press. New York., p. 295 (1975).

12. Neison, R. D., Quie, P. G., and Simons, R. L.: Chemotaxis under agarose: A new and simple method for measuring chemotaxis and spontaneous migration of human polymorphonuclear leukocytes and monocytes. J. Immunol., 115: 1650 (1975).

13. Pahwa, S. G., Pahwa, R., Grimes, E., and Smithsick, E.: Cellular and humoral components of monocyte and neutrophil chemotaxis in cord blood. Pediatr. 
Res., 11: 677 (1977).

14. Scatchard, G.: The attractions of proteins for small molecules and ions. Ann. N. Y. Acad. Sci., 51: 660 (1949).

15. Schiffmann, E., Corcoran, B. A., and Aswanikumar, S.: Molecular events in the response on neutrophils to synthetic N-F.Met chemotactic peptides: Demonstration of a specific receptor. Gallin, I. J. and Quie, P. G., (eds) "Leukocyte chemotaxis" Raven Press. New York, p. 97 (1978).

16. Spillberg, I. and Mehta, J.: Demonstration of a specific neutrophil receptor for a cell-derived chemotactic factor. J. Clin. Invest., 63: 85 (1979).

17. Synderman, R., Pike, M. C., and Dredich, N. M.: Role of transmethylation reactions in cellular motility and phagocytosis. Mol. Immunol., 17: 209 (1980).
18. Tonooka, T., Nakayama, M., Uehara, H., and Matsumoto, S.: Characteristics of impaired chemotactic function in cord blood leukocytes. Pediatr. Res., 13: 148 (1979).

19. Williams, L. T., Synderman, R., Pike, M. C., and Lefkositz, R. J.: Specific receptor sites for chemotactic peptides on human polymorphonuclear leukocytes. Pro. Natl. Acad. Sci. USA., 74: 1204 (1977).

20. Requests for reprints should be addressed to: Dr. Nunoi, H. Department of Pediatrics, Kumamoto University Medical School, Honjo, Kumamoto 860 JAPAN.

21. Received for publication September 18,1981 .

22. Accepted for publication May 18, 1983. 